\title{
A New Report of Uropyxis daleae in the Andes Range Mountains of Atacama Desert, Chile
}

\section{Germán Sepúlveda1 (iD*, Wilson Huanca-Mamani1 ${ }^{\circledR}$, Mabel Arismendi1 ${ }^{1}$ Mauricio Salazar ${ }^{2}$ (D), Bernardo A. Latorre ${ }^{3}$}

${ }^{1}$ Facultad de Ciencias Agronómicas, Universidad de Tarapacá, Arica, Chile

${ }^{2}$ Museo Micológico-MMUNM, Facultad de Ciencias, Universidad Nacional de Colombia, Medellín, Colombia

${ }^{3}$ Pontificia Universidad Católica de Chile, Santiago, Chile

Email: *gsepulve@uta.cl

How to cite this paper: Sepúlveda, G., Huanca-Mamani, W., Arismendi, M., Salazar, M. and Latorre, B.A. (2021) A New Report of Uropyxis daleae in the Andes Range Mountains of Atacama Desert, Chile. Advances in Microbiology, 11, 327-334. https://doi.org/10.4236/aim.2021.116025

Received: May 6, 2021

Accepted: June 26, 2021

Published: June 29, 2021

Copyright $\odot 2021$ by author(s) and Scientific Research Publishing Inc. This work is licensed under the Creative Commons Attribution International License (CC BY 4.0).

http://creativecommons.org/licenses/by/4.0/

\begin{abstract}
A rust disease caused by Uropyxis daleae (Dietel \& Holw.) Magnus was registered on the natural population of Dalea pennelli (Mac Bride) Mac Bride var. chilensis Barneby in the highland near the Andes in the northernmost of Chile. This pathogen shows uredinia with the presence of paraphyses and features, larger urediniospores and teliospores than $U$. daleae (Dietel \& Holway) Magn. var. daleae. Based on morphological combined with $28 \mathrm{~S}$ sequence analysis, we propose this pathogen as a new fungal variety: $U$. daleae var. socoromensis. This is the first report of Uropyxis daleae var. socoromensis attacking $D$. pennelli var. chilensis in Northern Chile.
\end{abstract}

\section{Keywords}

Uredinales, Neotropic Fungi, Endemic Fungi, Atacama Desert

\section{Introduction}

Dalea pennellii (J. F. Macbr.) J. F. Macbr. var. chilensis Barneby (Fabaceae), commonly known as "retamilla," is a small endemic shrub distributed in the highlands in northern Chile and southern Peru, above $3500 \mathrm{~m}$ above sea level (asl) [1]. It is a typical plant component of the native flora of arid landscapes [2]. In Chile, there is no information regarding the fungal species associated with this host plant. However, a rust fungus has been found attacking D. pennellii var. chilensis developing dusty black sori on the leaflets and stems. The rust fungi are a monophyletic, highly specialized group of obligate parasites in the phylum Basidiomycota, with a complex life cycle. Most of the rust fungi exhibit a high degree of host specificity [3]. 
Nowadays, the identification of rust fungi includes morphological and molecular studies [3] [4] [5]. The cell wall thickness, ornamentation, color, size, and shape of the telia and teliospores, and the pedicel characteristics and number and position of the germinative pores in the teliospores are important taxonomical features in the identification of rust fungi.

The Uredinales associated with native plants have been scarcely studied in Northern Chile but, some rust fungi have been described in coastal range and coastal valleys [6]. This study aims to report and describe a rust fungus associated with the canopy of $D$. pennellii var. chilensis, in Socoroma, Chile.

\section{Materials and Methods}

\subsection{Sample Collection}

Samples of $D$. pennellii var. chilensis were collected in Socoroma $\left(18^{\circ} 16^{\prime} 38^{\prime \prime S}\right.$, $69^{\circ} 35^{\prime} 28^{\prime \prime} \mathrm{W}$ ) in the highlands of the Andes mountains at $3200 \mathrm{~m}$ asl. D. pennellii var. chilensis were growing in a slope with a northern exposure, $125 \mathrm{~km}$ northeast of Arica city and $3 \mathrm{~km}$ from Socoroma, in the north of Chile (Figure 1). A total of 10 entire plants of $D$. pennellii var. chilensis showing rust, symptoms, and signs on the leaflets were collected in April and June 2017. Each sample was identified, labeled, and taken to the Plant Pathology Laboratory at Universidad de Tarapacá, where morphological and molecular studies were conducted. Besides, ten plant samples were desiccated at room temperature $\left(20^{\circ} \mathrm{C}-22^{\circ} \mathrm{C}\right)$ and kept in a herbarium.

\subsection{Morphological Studies}

Morphometric studies were conducted on water mount urediniospores and teliospores collected from rust sori developed on leaflet samples of $D$. pennellii var. chilensis.
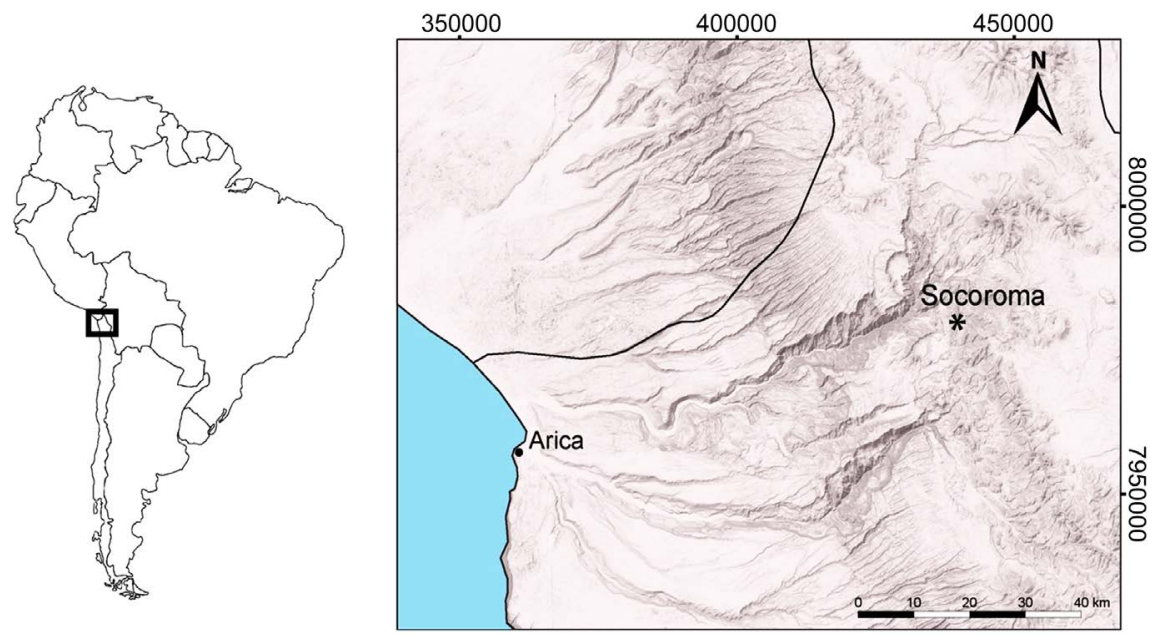

Figure 1. South American map showing northern Chile, the geographical location of Socoroma and the sample collection point (asterisk) of "retamilla" rust (Daleae pennellii var. chilensis). 
The identification included studies of wall thickness, ornamentation, color, size, and shape of the 30 urediniopores and 30 teliospores. The characteristics of the teliospore pedicels and the number and position of the germinative pores and spore size were determined. An aqueous solution of chloral hydrate $450 \mathrm{~g} / \mathrm{L}$ was used to facilitate seeing the germinal pores of the teliospores [7]. For the observation of morphological details of the spores, the Bruzesse and Hassan dye [8] was used. The preparations were sealed with nail polish, labeled, and stored at room temperature until used. Measurements and digital photographs were made with the aid of an Olympus BX51 microscope and the Q Capture-Pro version 6 Software (Surrey, BC, Canada).

For scanning electron microscope (SEM) EVO LS 10 (Carl Zeiss, Bonn, Germany) observations, where sections of leaflets of $\left(0.2 \mathrm{~cm}^{2}\right)$ with telia were obtained. The specimens were mounted on aluminum sample holders with double-contact carbon adhesives and analyzed in a low vacuum and in variable pressure mode, where the chamber pressure was $150 \mathrm{~Pa}$ (under vacuum) and in the column $2 \times 10^{-5}$ Torr (high vacuum). The working distance used (WD) varied depending on the type of sample, and what was needed to observe, the acceleration voltage used was $15 \mathrm{KV}$ and a tilt (tilt) from $0^{\circ}$ to $90^{\circ}$, while the images were taken with a resolution of $3024 \times 2304$ pixels at a scanning speed of 12 minutes with 54 seconds.

The specimens were deposited in the mycological collection of Universidad de Concepción Herbarium (CONC-F 1894).

\subsection{Molecular and Phylogenetic Analysis}

Due to rust cannot be grown in culture media, teliospores were used for molecular analysis, which was removed and collected from telia on leaves with a sterile scalpel. DNA from three independent infected plants was extracted using EZNA $^{\circledast}$ Insect DNA Kit (Omega Bio-Tek Inc, Norcross, GA, USA) according to the manufacturer's instructions. Subsequently, the D1/D2 domain of the large subunit ribosomal DNA 28S (LSU rDNA) was amplified using primers LR6 (5'-CGCCAGTTCTGCTTACC-3') and Rust2inv

(5'-GATGAAGAACACAGTGAAA-3') [9]. Polymerase chain reactions of LSU rDNA were conducted in an Amplitronyx ${ }^{\circledast} 6$ thermal cycler (Nyx-Technik, San Diego, California, USA) using a final volume of $20 \mu \mathrm{l}$. Each reaction contained 1 $\mu \mathrm{l}$ of DNA extract, 5 pmoles of each primer, $2.5 \mathrm{mM}$ of each dNTP, $2 \mathrm{mM}$ $\mathrm{MgCl}_{2}, 1 \mathrm{X}$ PCR buffer (KCl), 1 unit of Taq DNA polymerase (Thermo Scientific, Waltham, MA, USA), and sterile distilled water. Cycling conditions were: $5 \mathrm{~min}$ at $94^{\circ} \mathrm{C}$; 35 cycles of $1 \mathrm{~min}$ at $94^{\circ} \mathrm{C} ; 1 \mathrm{~min}$ at $55^{\circ} \mathrm{C} ; 1 \mathrm{~min}$ at $72^{\circ} \mathrm{C}$ and a final elongation step of $2 \mathrm{~min}$ at $72^{\circ} \mathrm{C}$. PCR blank reaction control without template DNA was always incorporated. The PCR products were visualized on $1.0 \%$ agarose gel and stained with GelRed (Biotium Inc., Hayward, CA, USA). The amplified PCR products were purified and sequenced by Macrogen (Macrogen, Geumcheon-gu, South Korea). The nucleotide sequences were visualized and edited using the 4 Peaks software (http://nucleobytes.com). A BLASTn analysis 
was used to compare the DNA sequence obtained of the rust fungus isolates from Socoroma with rDNA D1/D2 data sequences available in GenBank (http://www.ncbi.nlm.nih.gov/).

Phylogenetic reconstruction was performed using the maximum likelihood algorithm, using Molecular Evolutionary Genetics Analysis (MEGA version 6.0) software [10], and the robustness of the branches was assessed by bootstrap analysis [11] of 1000 replicates. The sequence of Encyclometra sp. (KY781819) was used as an outgroup.

\section{Results}

\subsection{Taxonomy}

Uropyxis daleae (Dietel \& Holw.) Magnus var. nova socoromensis.

Holotype. Dalea pennelli (Mac Bride) Mac Bride var. chilensis Barneby, Socoroma, Arica and Parinacota, Chile, Sep. 2017, leg. G. Sepúlveda 101 ColMic-UTA 183. The specimen was deposited as a dried specimen in the the mycological collection of Universidad de Concepción Herbarium (CONC-F 1894).

Etymology. From the Andean village of Socoroma, in reference to the collection site (Figure 1).

\subsection{Description}

Uredinial stage with amphiphigenous subepidermal uredinia with inconspicuous rupture of the epidermis, reddish to tan-brown, pulverulent, solitary or in small groups, round to oblong. Paraphyses not observed. Ellipsoid to obovoid urediniospores, hyaline to pale yellow, of $22-28 \times 20-23 \mu \mathrm{m}$, finely echinulate wall of $2-2.5 \mu \mathrm{m}$ of thickness, golden brown with 5 to 8 scattered germinative pores (Table 1).

Telia were anfigenous, subepidermal in origin, with inconspicuous epidermal rupture, dark brown to black, predominantly hypophyllous, frequently coming from uredinium, pulvinate, paraphyses were absent-Teliopores were bicellular, ellipsoid to oblong, $32-50 \times 25-30 \mu \mathrm{m}$. Uniform laminate wall, with scattered warts, $2.5 \mu \mathrm{m}$ thick and hyaline, two germinating pores per cell; fragile pedicel, $30-35 \mu \mathrm{m}$ long, hygroscopic at the point of union with the spore, up to $23 \mu \mathrm{m}$ wide, hyaline in color. Spermogonia (pycnial) and aecia were absent.

\subsection{Specimens Studied}

Fresh leaves of Dalea pennelli (Mac Bride) Mac Bride var. chilensis Barneby, Socoroma, Arica and Parinacota, Chile. 2017, Province of Parinacota, Socoroma, $\mathrm{S}$ lat. $18^{\circ} 16^{\prime} 38^{\prime \prime}, \mathrm{W} 69^{\circ} 35^{\prime} 28^{\prime \prime}, 3200 \mathrm{~m}$ asl. Leg. et det. W. Huanca-Mamani \& G. Sepúlveda, (CONC-F 1894).

Spermogonia (pycnia) and aecia were not detected. Sori containing teliospores, hypophyllous subepidermic, erumpents, small, dark brown, $1-2.1 \times 1-$ $1.8 \mathrm{~mm}$, powdery, non-paraphysated (Figure 2). Teliospores elipsoides to oblong $32-50 \times 25-30 \mu \mathrm{m}$, echinulated, dark brown, two germinative pores per 

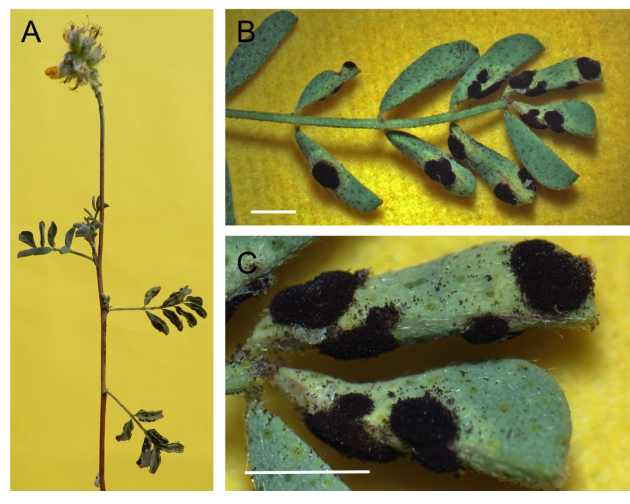

Figure 2. Signs and symptoms of "retamilla" rust (Daleae pennellii var. chilensis). (A) Telia on "retamilla" stems. (B) and (C) Slight chlorosis and dark brown to dusty black telia on "retamilla" leaf. Bar $=2 \mathrm{~mm}$.

Table 1. Morphological characterization of the telia and teliospores of Uropyxis daleae var socoromensis isolates from Dalea pennelli var. chilensis collected in Socoroma, an Andean village located at $3500 \mathrm{~m}$ asl near Arica in Northern Chile.

\begin{tabular}{|c|c|c|}
\hline Criteria & U. daleae $e^{1}$ & $U$. daleae var. socoromensis \\
\hline \multicolumn{3}{|c|}{ Teliospores } \\
\hline Size & $35-50 \times 24-30 \mu \mathrm{m}$ & $32-50 \times 25-30 \mu \mathrm{m}$ \\
\hline Shape & Ellipsoid & Ellipsoid to oblong \\
\hline Spore surface & Verrucose, echinulate & Verrucose, echinulate \\
\hline Spore ends & Rounded & Rounded \\
\hline Wall & Laminate & Laminate \\
\hline Wall thickness & $4-6 \mu \mathrm{m}$ & $1.3-3.3 \mathrm{~mm}$ \\
\hline Wall inner layer & Dark brown & Dark brown \\
\hline Wall outer layer & Yellowish & Hyaline to yellowish \\
\hline Pedicel attachment & Swelling & Swelling \\
\hline Pedicel wideness & $15-20 \mu \mathrm{m}$ & $23 \mu \mathrm{m}$ \\
\hline Pedicel length & $35 \mu \mathrm{m}$ & $30-35 \mu \mathrm{m}$ \\
\hline Germinative pores per cell & 2 & 2 \\
\hline Septum constriction & Slightly or absent & Slightly or absent \\
\hline \multicolumn{3}{|c|}{ Telia } \\
\hline Size & $0.5-1.0 \mathrm{~mm}$ in diameter & $1-2.1 \times 1-1.8 \mathrm{~mm}$ \\
\hline Color & Brown to black & Dark brown to black \\
\hline Aspect & Pulverulent & Pulverulent \\
\hline Origin & & Subepidermic \\
\hline Paraphyses & Peripheral & Non observed \\
\hline
\end{tabular}

${ }^{1}$ Based on Baxter's description (1959) [12].

cell, walls of uniform thickness $1.3-3.3 \mathrm{~mm}$, the majority $2.5 \mathrm{~mm}$ thick, pedicellated, hyaline pedicels, campanulated lateral wall of $14.3-10 \mathrm{~mm}$ of thickness, the majority of $12.5 \mathrm{~mm}$ thicks (Figure 3 ).

To confirm the morphological identification, a PCR fragments of LSU rDNA of isolates from Socoroma were successfully amplified and sequenced, obtaining fragments of LSU of 1446, 1456 and $1443 \mathrm{bp}$, which were deposited in the Gen- 
Bank (Accession number MG969964, MN337264 and MN337263, respectively). A BLAST search showed $91.20 \%$ similarity of the isolates Socoroma with Uropyxis daleae (KY798364) and 87.85\%, 87.78\%, and $87.76 \%$ with Puccinia ocimi, P. unciniarum, and P. caricis, respectively (KY764149, KX985746, and KX798380). The phylogenetic analysis using sequences of the LSU rDNA grouped the isolates Socoroma in a different cluster from other rust fungi, and it was phylogenetically close to the reference isolate of $U$. daleae (KY798364) (Figure 4).
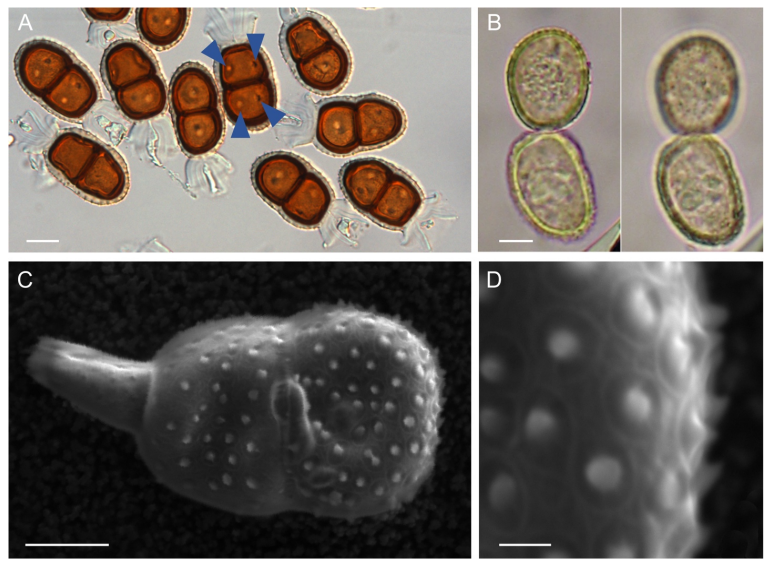

Figure 3. Uropixys daleae var. socoromensis. (A) Dark bicellular teliospores, verrucose to echinulate, with a brown inner layer a hyaline outer layer, two germinative pores (blue arrowhead), and a campanulate pedicel. (B) Ellipsoid to obovoid unicellular urediniospores with gray to yellow walls. (C) and (D) Teliospores under scanning electron microscopy. Echinulate surface and detail of teliospore pedicel $(C)$. Detail of teliospore surface showing scars and spines. Bars: $(A)-(C)=10 \mathrm{~mm},(D)=1 \mathrm{~mm}$.

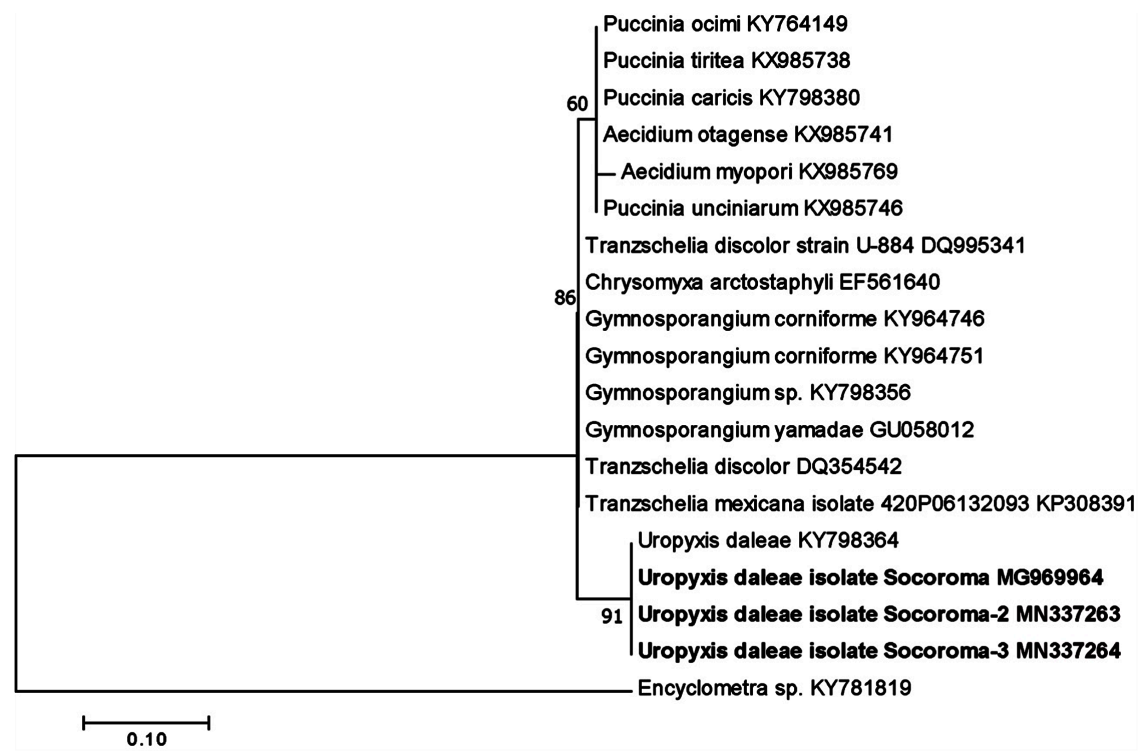

Figure 4. Phylogenetic tree based on LSU analysis of Uropyxis dalea var. socoromensis and close Basidiomycota species using the Kimura two-parameter model and maximum likelihood algorithm with 1000 bootstrap replicates. The new $U$. daleae sequences generated for this study are indicated in bold type. Numbers at nodes represent bootstrap support values. Encyclometra sp. was used as an outgroup for rooting purposes. 


\section{Discussion}

In this study, a rust fungus attacking $D$. pennelli ("retamilla") was characterized and identified as Uropyxis daleae, and based on morphological and molecular differences, a new variety, $U$. daleae var. socoromensis, is proposed. Rust fungi are very specific obligate parasites. To our knowledge, $U$. daleae var. socoromensis was only found on "retamilla" growing above $3500 \mathrm{~m}$ asl in the Andes Mountains in Northern Chile, where a high frequency of endemic plant species, animals, and fungi have been described [13]. Therefore, it is possible that this new variety of $U$. daleae may have coevolved in situ with its plant host. At present, "retamilla" grows as a wild shrub; however, it has a high potential as an ornamental plant.

The genus Uropyxis J. Schröt. (Basidiomycota, Pucciniales, Uropyxidaceae), was first distinguished from Puccinia spp. in 1875 by the presence of teliospores with two germination pores in each cell [11]. Nowadays, 30 species have been identified in the genus Uropyxis, two var. in U. steudneri and three in $U$. daleae. The recognized varieties of $U$. daleae are africana, daleae, and eysenhardtiae (Index Fungorum 2019, http://www.indexfungorum.org/, Mycobank 2019, http://www.mycobank.org/).

Based on morphological and msolecular results obtained in this study, $U$. daleae var. socoromensis is described as a new fungal variety. The main distinguishing characters of $U$. daleae var. socoromensis are the bigger urediniospores with uniform walls up to $2.5 \mu \mathrm{m}$ thick, uredinia with scattered paraphyses, and teliospores up to $50 \mu \mathrm{m}$ long. It differs from $U$. daleae (Dietel \& Holway) Magn. var. daleae by the size of the urediniospores and the wall, longer teliospores with smaller wall size, and telia lack of paraphysis. It differs from $U$. daleae (Dietel \& Holway) J.W. Baxter var. erysenhardtiae by the absence of spermogonia, aecia uredinoid, and the urediniospore size and wall thickness.

The presence of uredinia distinguishes $U$. daleae var. socoromensis from $U$. farlowii (Arthur) J.W. Baxter, a rust fungus that is also parasite Dalia spp., but apparently lacks of the uredinial stage.

Therefore, Uropyxis daleae var. socoromensis is described for the first time attacking $D$. pennelli var. chilensis in Northern Chile. Previously, only $U$. naumanniana has been reported in southern Chile [14].

\section{Acknowledgements}

We thank to Professor B. Arriaza and Professor E. Belmonte, Universidad de Tarapacá, Arica, Chile, for their help with SEM image, and the identification of Dalea pennellii, respectively. This work was funded by Gobierno de Chile, Ministerio de Educación, Convenio Desempeño en Educación Superior UTA1795 (Arica-Chile).

\section{Conflicts of Interest}

The authors declare no competing interests. 


\section{References}

[1] Barneby, R.C. (1990) Two New Taxa in Dalea (Fabaceae: Amorpheae) from Southern Mexico and Northern Chile. Brittonia, 42, 89-91. https://doi.org/10.2307/2807618

[2] Muñoz, A. and Bonacic, C. (2006) Seasonal Floristic and Vegetational Change in the Pre-Andean Mountain in Putre County (I Region of Tarapacá, Chile), during 2002 and 2003. Gayana. Botánica, 63, 75-92. https://doi.org/10.4067/S0717-66432006000100003

[3] Kolmer, J.A., Ordonez, M.E. and Groth, J.V. (2009) The Rust Fungi. In: Encyclopedia of Life Sciences (ELS), John Wiley \& Sons, Ltd., Chichester. https://doi.org/10.1002/9780470015902.a0021264

[4] Aime, M. (2006) Toward Resolving Family Level Relationships in Rust Fungi (Urediniales). Mycoscience, 47, 112-122. https://doi.org/10.1007/S10267-006-0281-0

[5] Hyde, K.D., Nilsson, R.H., Alias, A., et al. (2014) One Stop Shop: Backbones Trees for Important Phytopathogenic Genera: I. Fungal Diversity, 67, 21-125. https://doi.org/10.1007/s13225-014-0298-1

[6] García-Hernández, P., Rojas-Jara, M. and Sepúlveda-Chavera, G. (2008) Presencia de Uromyces limonii (DC) Lév. (roya del Limonium): Primer registro para el valle de Lluta, Región de Arica y Parinacota. IDESIA, 26, 73-75. https://doi.org/10.4067/S0718-34292008000100010

[7] Keane, P.J., Limonglello, N. and Warren, M.A. (1988) A Modified Method for Clearing and Staining Leaf-Infecting Fungi in Whole Leaves. Australasian Plant Pathology, 17, 37-38. https://doi.org/10.1071/APP9880037

[8] Bruzzese, E. and Hassan, S. (1983) A Whole Leaf Clearing and Staining Technique for Host Specificity Studies of Rust Fungi. Plant Pathology, 32, 335-338. https://doi.org/10.1111/j.1365-3059.1983.tb02841.x

[9] Fell, J.W., Boekhout, T., Fonseca, A., Scorzetti, G. and Statzell-Tallman, A. (2000) Biodiversity and Systematics of Basidiomycetous Yeasts as Determined by Large-Subunit rDNA D1/D2 Domain Sequence Analysis. International Journal of Systematic and Evolutionary Microbiology, 50, 1351-1371. https://doi.org/10.1099/00207713-50-3-1351

[10] Tamura, K., Stecher, G., Peterson, D., Filipski, A. and Kumar, S. (2013) MEGA6: Molecular Evolutionary Genetics Analysis Version 6.0. Molecular Biology and Evolution, 30, 2725-2729. https://doi.org/10.1093/molbev/mst197

[11] Felsenstein, J. (1985) Confidence Limits in Phylogenies: An Approach Using the Bootstrap. Evolution, 39, 783-791. https://doi.org/10.1111/j.1558-5646.1985.tb00420.x

[12] Baxter, J.W.A. (1959) Monograph of the Genus Uropyxis. Mycologia, 51, 210-226. https://doi.org/10.1080/00275514.1959.12024814

[13] Buriticá, P., Salazar, M. and Pardo, V.M. (2014) Pucciniales (Fungi), Royas de Colombia. Revista Facultad Nacional de Agronomía, 67, S1-S93.

[14] Mujica, F. and Vergara, C. (1980) Flora Fungosa Chilena. Ciencias agrícolas $N^{\circ} 5$, Facultad de Agronomía, Universidad de Chile, Santiago Chile. 